\title{
SMEs E-Business Behaviour: A Demographics and Strategic Analysis
}

\author{
Ilias P. Vlachos \\ Associate Professor, Athens, Greece
}

\begin{abstract}
The aim of this research was to understand the strategic uses of e-business systems and technologies by classifying companies and particularly small and medium businesses according to demographics as well as e-business behavior variables.The study was based on data from a large quantitative survey of European E-business W@tch for the period 2007 using questionnaire interviews $(\mathrm{N}=409)$. We employed two-step cluster analysis, multinomial logistic regression and stepwise descriminant analysis as the most appropriate methods for our analysis. The findings revealed six clusters associated to e-business adoption. The six groups differ in terms of demographic characteristics as well as e-business applications they use. We found that the following clusters exist: (a) Leaders: large companies that extensively use ebusiness in a strategic manner (b) innovators: use e-business in an way that allows them to innovate and differentiate from other companies (c) Beginners: small and medium companies across all sectors that only recently start to use e-business (d) Unready Adopters: micro and small companies that lag behind (e) Late Adopters: small-size companies but larger that the Unready Adopters, that appear not to be interest in the advances of ICTs and (f) Laggards: micro companies with little use of e-business. The results of our survey can positively contribute to managers aiming to take advantage of technological advances in electronic business as well as to any researcher who study e-business management and applications.
\end{abstract}

Keywords: SMEs, E-business, Competitive behaviour, Cluster Analysis

\section{Introduction}

In many cases, e-business is a truly innovative means to manage and compete in the global business settings. According to a recent survey of Sectored e-Business Watch (Selhofer et al. 2007), which was supported by the European Commission, in 29 European countries; $64.2 \%$ of companies has already adopted e-business applications, while $54.5 \%$ of these businesses have mentioned positive changes to their operation, managing to increase their competitive attitude almost by $47.2 \%$. Yet, other companies, including SMEs, lag behind and do not follow leading companies in taking advantage ofebusiness applications. Hidding (2001) suggested that the velocity of e-business adoption is a matter of each sector's dynamics and strategy paradigms against new technologies. Furthermore, the same researcher remarked that e-business is a continuous process, which can alter business competitive attitude within the sector, a fact which underlines the business clusters' existence. Therefore, the technological differentiation and the extent of e-business diffusion can provoke creation of business groups of common characteristics within comparable sectors. The relation of e-business adoption with organizational performance has studied extensively over time but results seem to be inconsistent, particularly when bringing contextual variables into the equation. For example, Ozer (2002) highlighted the combination of managerial tasks and e-

Copyright (C) 2011 Ilias P. Vlachos. This is an open access article distributed under the Creative Commons Attribution License unported 3.0, which permits unrestricted use, distribution, and reproduction in any medium, provided that original work is properly cited. Contact author: Ilias P. Vlachos e-mail: ivlachos@aua.gr 
business applicability and tried to emphasize that the growing customers' demands is one of the managerial aspects that each firm needs to seriously consider in order for e-business strategy to be more effective. Pavic et al. (2007) measured the diverse challenges which e-business provoke and found that demographic factors, such as business explain to a large extend e-business success on internal process. Xirogiannis and Glykas (2007) affirmed that e-business could provide superior value to business customers, while Phan (2003) suggested e-business as an appropriate managerial tool that each company needs to adopt in order to differentiate its operations from competitors.

This paper is based on the assumption that the adoption of various types of information systems and technologies by Small and Medium-sized Enterprises (SMEs) is revealing of the strategic orientation of SMEs. Creating profiles of SMEs based on their e-business behaviour helps us connect demographic variables with strategic options, thus uncovering hidden patterns of information systems development.

The assumption grew out of a widely held view that e-business plays a critical part in helping organisations reconstruct, renovate, and metamorphose internal processes in order to increase efficiency, effectiveness and competitiveness (Eikebrokk and Olsen, 2007; Boutilier and McNaughton, 2006; Guerrieri and Meliciani, 2005; Lan and $\mathrm{Du}, 2002$ ). Consequently, a set of questions can be generated according to e-business penetration among businesses: 'Which are the factors that differentiate business behaviour regarding e-business adoptability' and then 'How e-business applications can potentially generate dissimilar business groups with common attitudes?'. 'Is it only demographic variables or a set of e-business applications that can create different e-business profiling groups?'

\section{E-business Strategies for SMEs in Relation to Business Performance}

According to Stone (2003) e-business adoption by SMEs and large corporations usually follows a similar normal diffusion curve, in which the technological effectiveness between "Early adopters" and "Laggards" has a time gap more than 20 years. Stone (2003) investigated the relation between the e-business applications and customers expectations finding critical factors of e-business success towards customer relation management (CRM) such as web site quality, value proposition and trusted brand. Stone (2003) defined a 3-stage model related to continued technological investments and technical applications that usually occurred in business environment; and named these groups as "Early adopters", "Integrating adopters" and "Advanced adopters". Stone (2003) concluded that 'SMEs are keen to adopt new technological applications quickly and cost effective in comparison to large businesses which usually operate under complexity and non-flexibility procedures'. Furthermore, the researcher recognised that businesses' attitudes, after technological investments, are significantly dependent on a sector's competitiveness and issues of 'good-will' (Hedelin and Allwood, 2002). Salmela and Spil (2002) remarked the importance of innovation management related to e-business applications as an informal and continual planning process so as to ensure flexibility, creativity and strategic thinking to their emergent policies. Researchers urged the need for a dominant organizational process to ensure a non-stop strategic alignment among businesses. Salmela and Spil (2002) suggested a 4-cycle method divided into four-planning steps:

1. 'Agreeing on planning objectives',

2. 'Aligning business and information objectives',

3. Analysing ICT resources with the respective infrastructure', and 
4. 'Authorising actions'. Researchers found that e-business adoption is a matter of organizational flexibility, a necessary path of development, which businesses need to follow in order to successfully integrate the operational process with business goals. In this direction, the most applicable e-business model will be preferred by 'good management practices' in order to meet at least the minimal requirements, such as financial resources and ICT infrastructure; a fact which could provide a more competitive behaviour and cost-benefit policy. However, the adoption and utilization of new technological models have to be proposed under extensive internal investigation by ICT executives; a policy which unfortunately many businesses, independently of their size, fail to adopt (Morgan at al, 2006).

Horner-Long and Schoenberg (2002) aimed to measure the different business profiles as well compare leadership between traditional 'bricks \& mortars' businesses with e-businesses. Researchers used a sample of 400 randomly selected top-businesses from leading UK food industries, half of which had already established a substantial e-business infrastructure. They found that the leadership awareness of 'brick \& mortars' towards collaboration, product development and new markets identification was significantly low and was mostly limited to charities development (Parsons, 2002). This means that leaders in such traditional businesses usually target to 'stay alive' in competition rather than innovate technologically.

In the case that such (traditional) leaders wish to follow a more competitive strategy based on digital requirements, this path could take a short time, due to the sector's traditional stability, a fact which means that in most cases this strategy is overruled. On the other hand, corporations with e-business applications usually operate in a rapidly changing environment, where demand for new products development and new quality services are a continuous process meaning that internal structure is always redesigned to meet customer's expectations (Falk, 2005).
Collaborations and trust partnerships were rarely applied in this business area, except in the case of new markets development.

Lal (2005) used a different mix of variables in order to analyse and distinguish business behaviours related to e-business adopted applications. He measured variables such as demographic characteristics, export intensity, and profit margins, while his research sample was grouped into three business categories: 1) Offline businesses, 2) Online businesses, and 3) Portal using businesses.

Using a database from the Indian manufacturing sector, the researcher found that variables such as size of business can significantly differentiate operational behaviour, while the business's orientation can be measured with variables such as exports awareness and technological collaboration, which, in turn, can determine business performance.

Motiwalla et al. (2003) sought to measure the intra- and inter-industry financial performance of three industrial sectors: retail, consumer products, and food \& beverages and tobacco, in order to examine whether e-business applications are the appropriate managerial tool, which can affect financial performance.

The sample was collected from 165 companies from three different sectors by gathering the financial statements for a period of 10 years. Motiwalla et al. (2003) developed a financial model, which included a list of performance dependent variables, such as ROI (Return on Investment), ROA (Return on Assets), ROS (Return on Sales) as well as revenue growth, and found that those ratios are considered as the most crucial for measuring the financial performance of any business or industry related to applicable e-business strategies.

Furthermore, they found that e-business applications had a long-term impact on the intra-industry financial performance providing a higher net and gross profit, an inventory turnover, increased sales, and low operational costs in comparison to 
inter-industry financial performance. Hence, they urged that e-business applications can generate unlike financial business groups with different behaviour on sales' revenue, cost of producing goods or services, new investment policy, and service quality not only to industrial sector but also to inter- and intra- industrial area (Lu and Zhang, 2003).

Cuervo and Menendez (2006) examined the digital gap among 15 European countries and utilised cluster analysis in order to firstly identify a group of countries with common characteristics towards technological adoption and then to identify if the cost effect and governmental policies could influence e-business implementation. The researchers were successful in identifying four groups of common behaviour towards technological penetration:

Cluster 1 includes less developed countries regarding ICT penetration, Cluster 2 includes countries with less public eservices and high accessibility cost, Cluster 3 includes high public e-services and low accessibility cost and Cluster 4 includes countries with the largest ICT adoption. Accordingly, Greece was placed in Cluster 3. They found that cost is usually a business issue, which could dictate which e-business strategy could be the most suitable, leading to a high operational performance and high competitive pathway. Additionally, they affirmed that businesses in different countries have different e-business policies and consequently different business performances, due to a set of factors such as governmental support and cost of internet access. Indeed, regarding governmental financial support, Lasch et al. (2006) remarked that it is a critical success factor especially for start-up businesses related to any technological development.

Ledz and Nobis (2007) found four clusters using hierarchical cluster analysis to measure the business activities related to e-business applications in the geographical area of Germany. The most advanced cluster was cluster 4 described as the highest technologically penetrated one and included facilities such as e-shopping, increased e-mail usage, mobile applications through laptops, and high internet usage. Researchers found that e-business adoption is a matter of general digital awareness that businesses have towards competition and the individual's attempt towards future digital economy, which can transform the current business attitude by increasing the e-business adoptability (Lal, 2005). Harris et al. (2001) suggested that this adoption has to be proposed by ebusiness managers, following a strategic path of having, firstly extensive investigation of all the background information of the business and secondly taking into consideration the nature of the company and its needs for further development in relation to the external environment.

\section{E-Business Adoption in Greece}

In Greece, more than 95\% of companies are SMEs across all sectors (official statistics, 2005). Like any EU SMEs, a Greek SME is an enterprise: (a) which has fewer than 250 occupied persons, and (b) has either an annual turnover not exceeding [50] million euro, or an annual balance sheet total not exceeding [43] million euro, and (c) either does not belong to a group of linked enterprises, or it belongs to a group of linked enterprises that fulfils the conditions laid down in (a) and (b) above.

Xanthidis and Nicholas (2004) evaluated the existing technological implementation including the Internet in the public as well as business sector. Researchers made a quantitative survey and found unsurprisingly low Internet usage among Greek businesses. Additionally, the researchers asserted that although Greek small businesses (SMEs) have already adopted a set of technological applications, the lack of 'knowledge management' prevents businesses from adopting a complete e-business model. Thus, the business performance towards e-business applications is extremely negative in Greece and only scattered e-business adoptions take place. Papathanassiou et al. (2003) measuring the attitude of ecommerce in the Greek food sector, asserted that this behaviour can create 
different technological business groups with similar performances. Additionally, they argued that food and beverage sector has a great perspective for e-business development and stated that 'Price, brand name and logistics for convenience and preference are easily compared on web sites', meaning that businesses will take advantage of e-commerce sooner or later. Moreover, they asserted that only a very limited number of Greek food \& beverage SMEs $(27.1 \%)$ have recruited an IT executive team or even an IT executive. On the contrary, the great majority of companies use e-business for supporting purposes of regular, 'traditional' business activities (81.3\%). Papathanassiou et al. (2003) concluded that there is a need for ebusiness future investments, despite a low technological budget, which Greek SMEs plan to invest for e-business applications in the near future. Bakouros et al. (2002) highlighted that e-business implementation can be succeeded only by large Greek companies and not by SMEs due to the net profits and high competitive attitude, indicating that the firm's size is the most important factor for adopting e-business applications. Only a few SMEs can successfully adopt a set of e-business applications, mainly based on individual efforts of managers related to technological issues and high-levels of 'know-how' (Tsiamis, 2008).

\section{Methodology}

\section{Questionnaire Design}

This study was based on the research project of European e-Business Market Watch 2005 (Selhofer et al. 2007) in the European Union (EU) aiming to provide reliable empirical information about the factors which contribute to e-business development in Europe. In particular, eBusiness W@tch observatory did a survey on e-business maturity investigating the following areas: (a) ICT infrastructure and e-skills development in the company, (b) Ecommerce and e-business usage, (c) Impact of selling and procuring online, and (d) Impact of and satisfaction with electronic business. Results, reports, newsletters, statistics as well as Methodological limitations and details of survey and other material on e-business can be found at the e-Business W@tch website, as it has already been mentioned. Finally, the quantitative survey was employed using a computer-aided telephone interview We carefully evaluated all the variables and we decide to measure the ICT infrastructure and e-business applications in Greek entrepreneurship by measuring the following issues:

\section{- Module A: ICT infrastructure}

- Module B: ICT Expenditure and Investments

- Module C: Internal and External eCollaboration and e-applications

- Module D: Online Sourcing and Procurement

- Module E: Online Marketing and Sales

- Module F: Background Information about the Company (Demographic Variables)

Table 1 lists the variables which were used in the two-step cluster analysis. Variables were demographics (sector and size) and ICT and e-business applications which included the ICT infrastructure variables: type of internet access, E-applications: intranet, ERP, Knowledge Management Software, Accounting Software, Enterprise Document Management System, SCM (Supply Chain Management System), CRM (support marketing and online sales), EProcurement (how large a share of the total volume of your orders is placed online), Internal and External e-Collaboration (percentage of invoices received as einvoices; and percentage of invoices sent as e-invoices), Expenditure and Investments: (Share of ICT budget, including hardware, software, services and personnel, as percentage of the total costs in 2005).

All the categorical variables are presented in Table 1. These variables are divided into two groups: demographic and e-Business variables.

The former include: sector and size of the sampling; and the latter are associated with 
e-Business such as website, e-business technologies, e-orders, e-invoices, type of internet access and ICT budget. Each variable was assessed on categorical variable of 5-point scale apart from 2.3, 2.4, 2.5 and 2.6. Those variables are dichotomous.

Table 1: Categorical Variables Used in the Cluster Analysis

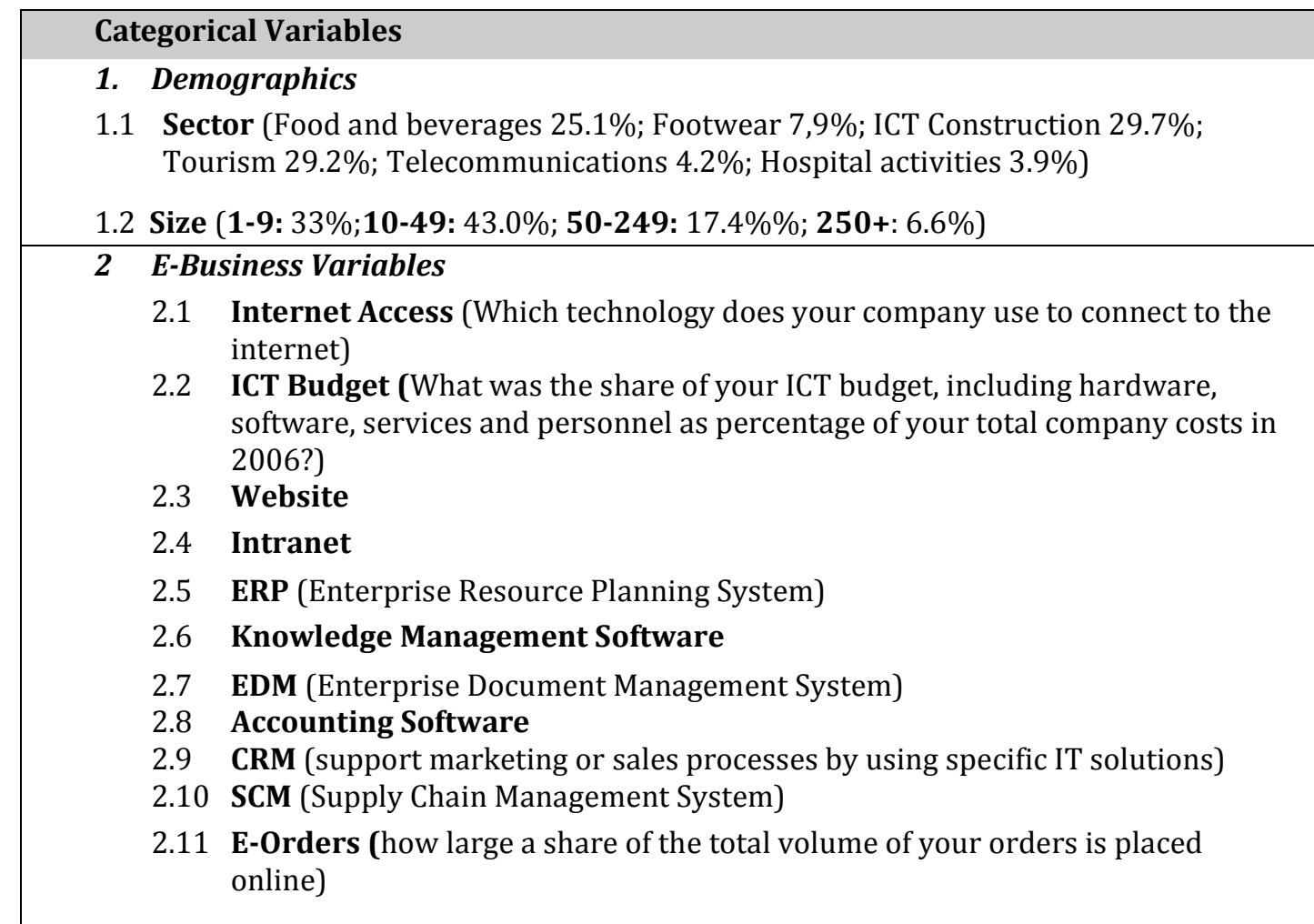

2.12 E-Invoices (Please estimate the percentage of invoices your company sends)

2.13 E-Invoices (Please estimate the percentage of invoices your company receives)

\section{Sample}

Data was collected by the European survey of the Sectored e-Business Watch, which included 407 Greek businesses from six different sectors. Additional information is available on the website of e-Business Market Watch (www.ebusiness-watch.org). Questionnaires were designed based on experience from previous surveys in order to assess the level and magnitude of adoption of e-business in EU companies. Data were collected by computer-assisted telephone interviews with managers over a few weeks in early 2007.

\section{Data Analysis}

We conducted a two-step cluster analysis using Two Step Cluster in SPSS v.15.0. The two-step Cluster Analysis is an exploratory tool designed to reveal natural groupings (or clusters) within a data set, which can be a mix of interval and nominal data (Okazaki, 2006).

For our purpose, we set two groups of variables: demographic and technological: The former are suitable due the nature of this research indicating potential areas of the technological characteristics of businesses among different Greek sectors. The latter are appropriate for pervasive 
use among different sectors measuring the impact of e-business on a firm's performance (Johnson et al. 2007; Cuervo and Menendez, 2006; Hayes and Finnegan, 2003). Hence, we consider two-step cluster analysis as the most appropriate methodological approach in order to distinguish different business clusters with great homogeneity of characteristics.

Two-step clustering generates pre-clusters and finally it clusters the pre-clusters. By using Principal Components Analysis (PCA), we attempted to analyse information from the variance related to the set of variables that we initially posed (Table 1). For this reason, we defined the pre-cluster method and by measuring the log-likelihood function and we managed to measure the variables distributions and to maximise the distance among clusters. Then, we used the Schwarz's Bayesian Criterion (BIC) as the most suitable clustering criterion avoiding alias in order to determine the number of clusters that fit better in the data. Using this criterion, six clusters were revealed as presented in Table 2.

Table 2: Cluster Distribution

\begin{tabular}{ccccc}
\hline & & N & \% of Combined & \% of Total \\
\hline Clusters & 1 & 64 & $16.0 \%$ & $15.7 \%$ \\
2 & 104 & $26.0 \%$ & $25.6 \%$ \\
3 & 59 & $14.8 \%$ & $14.5 \%$ \\
4 & 36 & $9.0 \%$ & $8.8 \%$ \\
5 & 81 & $20.3 \%$ & $19.9 \%$ \\
6 & 56 & $14.0 \%$ & $13.8 \%$ \\
& 400 & $100.0 \%$ & $98.3 \%$ \\
\hline \multicolumn{2}{c}{ Excluded Cases } & & & $1.7 \%$ \\
\multicolumn{2}{c}{ Total } & 407 & & $100.0 \%$
\end{tabular}

Table 3: Results of Auto-Clustering

\begin{tabular}{ccccc}
$\begin{array}{c}\text { Number of } \\
\text { Clusters }\end{array}$ & $\begin{array}{c}\text { Schwarz's } \\
\text { Bayesian Criterion } \\
\text { (BIC) }\end{array}$ & $\begin{array}{c}\text { BIC } \\
\text { Change(a) }\end{array}$ & $\begin{array}{c}\text { Ratio of BIC } \\
\text { Changes(b) }\end{array}$ & $\begin{array}{c}\text { Ratio of } \\
\text { Distance } \\
\text { Measures(c) }\end{array}$ \\
\hline 1 & 17413.623 & & & \\
2 & 15696.432 & -1717.190 & 1.000 & 2.030 \\
3 & 15032.864 & -663.568 & .386 & 2.048 \\
4 & 14892.714 & -140.150 & .082 & 1.161 \\
5 & 14821.808 & -70.906 & .041 & 1.105 \\
6 & 14791.668 & -30.140 & .018 & 1.111 \\
\hline 7 & 14800.416 & 8.748 & -.005 & 1.051 \\
8 & 14826.136 & 25.720 & -.015 & 1.669 \\
9 & 14985.601 & 159.465 & -.093 & 1.204 \\
10 & 15178.914 & 193.313 & -.113 & 1.131 \\
\hline
\end{tabular}

Notes:

a. The changes are from the previous number of clusters in the table.

b. The ratios of changes are relative to the change for the two cluster solution.

c. The ratios of distance measures are based on the current number of clusters against the previous number of clusters.

\section{Results}

\section{Demographic and E-business Application Profiling of $E$-business}

Demographic variables are suitable for streaming businesses into different sectors 
by providing conceptual similarities such as size and business sector. For example, Falk (2005) emphasized the significance of demographic profiling among industries by measuring attributes such as size of companies and sector segmentations. Regarding the first demographic variable, Table 4 shows that businesses recruited between 1 to 9 permanent employees (38.1\%), 10 to $49(26.3 \%), 50$ to 249 $(17.7 \%)$ and more than $250(4.8 \%)$ in comparison to Greek ratios 31.2\%, 43\%, $17.4 \%$ and $6.6 \%$ respectively (Selhofer et al. 2007). Moreover, the sector analysis shown that the beverage sector contributes $12.1 \%$, footwear $7 \%$, construction $18.9 \%$ is similar to tourism sector, telecommunications $11.2 \%$ and hospital activities $5.9 \%$ in comparison to Greek sectors $25.1 \%, 7.9 \%, 29.7 \%, 29.2 \%, 4.2 \%$ and $3.9 \%$ respectively.

According to the e-business applications, Table 4 shows that according European survey the ICT infrastructure is characterised by high DSL usage. In particular, the broadband internet access via DSL is $51.2 \%$, Broadband via Cable is $14.6 \%$, ISDN is $12.4 \%$ and $56 \mathrm{~K}$ (analogue) is $7.2 \%$ in comparison to Greek ratios42.8\%, 4.2\%, $29.5 \%$ and $10.3 \%$. Moreover, Tables 4 shows that ICT budgetbetween $1 \%$ and $4 \%$ is contributed to $37.6 \%$ and follows businesses with ICT budget between $5 \%$ to $9 \%(25.7 \%)$ and $10 \%-49 \%$ (25.4\%) respectively to Greek businesses $44.0 \%, \quad 44.0 \%$ and $8.4 \%$ respectively.

According to e-business applications European survey indicated: accounting applications (51.2\%), Intranet (37.8\%), ERP (21.6\%), EDM (19,6\%), CRM (14.9\%), SCM (14\%) and Knowledge Management (12.8\%) respectively to Greek businesses $54.8 \%, 39.6 \%, 28.3 \%, 15.5 \%, 15.2 \%, 16 \%$ and $11.1 \%$ respectively. Furthermore, related to online sales and marketing.

Table 4 shows that the website construction for European business is $67.7 \%$ while for Greek businesses it is lower (64.6\%). Additionally, the share volume for e-orders for European businesses between $0 \%$ and $4 \%$ is $16.4 \%$, while for Greek businesses it is $19.4 \%$ (it is surprising that in Greece $64.6 \%$ of businesses have e-orders between $5 \%$ to $9 \%$ ). Finally, Table 4 shows that $87.9 \%$ of the European businesses send e-invoices between $10 \%$ to $49 \%$ and $88.6 \%$ of them receive e-invoices as well, while the Greek ratios are $62.4 \%$ and $63.1 \%$ respectively. 
Table 4: Demographic and E-Business Applications Profiling

\begin{tabular}{|c|c|c|}
\hline & EU $(n=14065)$ & Greece $(n=407)$ \\
\hline \multicolumn{3}{|l|}{ Sector } \\
\hline Food and beverages & $12.1 \%$ & $25.1 \%$ \\
\hline Footwear & $7.0 \%$ & $7.9 \%$ \\
\hline Construction & $18.9 \%$ & $29.7 \%$ \\
\hline Tourism & $18.9 \%$ & $29.2 \%$ \\
\hline Telecommunications & $11.2 \%$ & $4.2 \%$ \\
\hline Hospital activities & $5.9 \%$ & $3.9 \%$ \\
\hline Other & $26 \%$ & - \\
\hline \multicolumn{3}{|l|}{ Size (number of employees) } \\
\hline $1-9$ & $38.1 \%$ & $31.2 \%$ \\
\hline $10-49$ & $26.3 \%$ & $43.0 \%$ \\
\hline $50-249$ & $17.7 \%$ & $17.4 \%$ \\
\hline $250+$ & $4.8 \%$ & $6.6 \%$ \\
\hline unknown & $13.1 \%$ & 0 \\
\hline \multicolumn{3}{|l|}{ Internet Access } \\
\hline $56 K$ (analogue) & $7.2 \%$ & $10.3 \%$ \\
\hline$I S D N$ & $12.4 \%$ & $29.5 \%$ \\
\hline Broadband via DSL & $51.2 \%$ & $42.8 \%$ \\
\hline Broadband via Cable & $14.6 \%$ & $4.2 \%$ \\
\hline Direct fibre connection & $6.4 \%$ & $2.2 \%$ \\
\hline Wireless broadband connection & $7.6 \%$ & $4.2 \%$ \\
\hline Other access & $4.4 \%$ & $6.9 \%$ \\
\hline \multicolumn{3}{|l|}{ ICT Budget } \\
\hline $0 \%$ & $8.9 \%$ & $2.5 \%$ \\
\hline $1 \%-4 \%$ & $37.6 \%$ & $44.0 \%$ \\
\hline $5 \%-9 \%$ & $25.7 \%$ & $44.0 \%$ \\
\hline $10 \%-49 \%$ & $25.4 \%$ & $8.4 \%$ \\
\hline $50 \%-100 \%$ & $2.4 \%$ & $1.2 \%$ \\
\hline \multicolumn{3}{|l|}{ E-Applications } \\
\hline Intranet & $37.8 \%$ & $39.6 \%$ \\
\hline$E R P$ & $21.6 \%$ & $28.3 \%$ \\
\hline Knowledge Management & $12.8 \%$ & $11.1 \%$ \\
\hline$E D M$ & $19.6 \%$ & $15.5 \%$ \\
\hline Accounting Software & $51.2 \%$ & $54.8 \%$ \\
\hline$S C M$ & $14 \%$ & $16 \%$ \\
\hline$C R M$ & $14.9 \%$ & $15.2 \%$ \\
\hline \multicolumn{3}{|l|}{ Marketing and Sales } \\
\hline Website Construction & $67.7 \%$ & $64.6 \%$ \\
\hline \multicolumn{3}{|l|}{ E-Orders } \\
\hline $0 \%-4 \%$ & $16.4 \%$ & $19.4 \%$ \\
\hline $5 \%-9 \%$ & $10.5 \%$ & $64.6 \%$ \\
\hline $10 \%-25 \%$ & $8.3 \%$ & $7.1 \%$ \\
\hline $26 \%-50 \%$ & $7.6 \%$ & $3.4 \%$ \\
\hline $51 \%-100 \%$ & $11.7 \%$ & $5.4 \%$ \\
\hline \multicolumn{3}{|l|}{ E-Invoices (send) } \\
\hline $1 \%-4 \%$ & $4.5 \%$ & $5.2 \%$ \\
\hline $5 \%-9 \%$ & $2.9 \%$ & $31.7 \%$ \\
\hline $10 \%-49 \%$ & $87.9 \%$ & $62.4 \%$ \\
\hline $50 \%-100 \%$ & $4.7 \%$ & $0.7 \%$ \\
\hline \multicolumn{3}{|l|}{ E-Invoices (received) } \\
\hline $1 \%-4 \%$ & $5.8 \%$ & $4.7 \%$ \\
\hline $5 \%-9 \%$ & $3.2 \%$ & $31.7 \%$ \\
\hline $10 \%-49 \%$ & $88.6 \%$ & $63.1 \%$ \\
\hline $50 \%-100 \%$ & $2.5 \%$ & $0.5 \%$ \\
\hline
\end{tabular}




\section{Attitudinal Profiling}

Table 5 presents the composition of demographic profiles within clusters while Table 6 presents the composition of demographic profile across cluster solutions.

Cluster 1 consisted of telecommunication sector $(65 \%)$ and represents companies with 10-49 employees (44\%). Cluster 2 consisted of hospitality activities (50\%) and employees between 10 and 49 individuals (63\%).
Cluster 3 included in construction sector (21\%) and number of employees between

1 to 9 permanent individuals (97\%). Cluster 4 consisted of telecommunication sector $(18 \%)$ and represent companies with 10-49 employees.

Cluster 5 included mainly companies of the footwear sector (34\%) and classes of employees between 1 and 9 (98\%). Cluster 6 included companies mainly from the construction sector (41\%) and food \& beverages (34\%). Most companies of Cluster 6 were small companies (98\%) having 1-9 employees.

Table 5: Composition of Demographic Profiles in Greece within Clusters $(n=407)$

\begin{tabular}{|c|c|c|c|c|c|c|c|}
\hline Greece & & $\begin{array}{c}\text { Clus } \\
\text { ter } 1 \\
(n= \\
64)\end{array}$ & $\begin{array}{c}\text { Cluster } \\
2 \\
(n=104 \\
)\end{array}$ & $\begin{array}{c}\text { Cluster } \\
3 \\
(n=59)\end{array}$ & $\begin{array}{c}\text { Clust } \\
\text { er } 4 \\
(n=3 \\
6)\end{array}$ & $\begin{array}{c}\text { Cluster } \\
5 \\
(n=81)\end{array}$ & $\begin{array}{c}\text { Clust } \\
\text { er } 6 \\
(n=5 \\
6)\end{array}$ \\
\hline \multicolumn{8}{|l|}{ Size (employees)(a) } \\
\hline & $\begin{array}{c}1-9 \\
10-49 \\
50-249 \\
250+\end{array}$ & $\begin{array}{c}3 \% \\
44 \% \\
34 \% \\
19 \%\end{array}$ & $\begin{array}{c}1 \% \\
63 \% \\
26 \% \\
11 \%\end{array}$ & $\begin{array}{c}97 \% \\
2 \% \\
0 \% \\
2 \%\end{array}$ & $\begin{array}{c}33 \% \\
50 \% \\
14 \% \\
3 \%\end{array}$ & $\begin{array}{c}0 \% \\
77 \% \\
21 \% \\
2 \%\end{array}$ & $\begin{array}{c}98 \% \\
2 \% \\
0 \% \\
0 \%\end{array}$ \\
\hline \multicolumn{8}{|l|}{ Sector ${ }^{(a)}$} \\
\hline Sector & $\begin{array}{c}\text { Food \& } \\
\text { beverage* } \\
\text { Footwear* } \\
\text { Constructi } \\
\text { on* } \\
\text { Tourism* }\end{array}$ & $\begin{array}{c}22 \% \\
0 \% \\
17 \%\end{array}$ & $\begin{array}{c}24 \% \\
9 \% \\
33 \%\end{array}$ & $\begin{array}{c}29 \% \\
5 \% \\
41 \%\end{array}$ & $\begin{array}{l}22 \% \\
14 \% \\
6 \%\end{array}$ & $\begin{array}{l}23 \% \\
14 \% \\
25 \%\end{array}$ & $\begin{array}{c}34 \% \\
7 \% \\
41 \%\end{array}$ \\
\hline & $\begin{array}{c}\text { Telecomm } \\
\text { unications } \\
* \\
\text { Hospital } \\
\text { activities* }\end{array}$ & $\begin{array}{l}41 \% \\
17 \% \\
3 \% \\
\end{array}$ & $\begin{array}{l}1 \% \\
8 \% \\
\end{array}$ & $\begin{array}{l}3 \% \\
3 \% \\
\end{array}$ & $\begin{array}{l}8 \% \\
0 \% \\
\end{array}$ & $\begin{array}{l}0 \% \\
5 \% \\
\end{array}$ & $\begin{array}{l}18 \% \\
0 \% \\
0 \% \\
\end{array}$ \\
\hline
\end{tabular}

Notes: (a) The numbers indicate percentages that vertically sum to $100 \%$. 
Table 6: Composition of Demographic Profiles in Greece across Clusters $(n=407)$

\begin{tabular}{|c|c|c|c|c|c|c|c|}
\hline Greece & & $\begin{array}{c}\text { Clust } \\
\text { er } 1 \\
(n=6 \\
4)\end{array}$ & $\begin{array}{c}\text { Clust } \\
\text { er } 2 \\
(n=1 \\
04)\end{array}$ & $\begin{array}{c}\text { Clust } \\
\text { er } 3 \\
(n=5 \\
9)\end{array}$ & $\begin{array}{c}\text { Clust } \\
\text { er } 4 \\
(n=3 \\
6)\end{array}$ & $\begin{array}{c}\text { Clust } \\
\text { er } 5 \\
(n=8 \\
1)\end{array}$ & $\begin{array}{c}\text { Cluster } \\
6 \\
(n=56)\end{array}$ \\
\hline \multicolumn{8}{|c|}{ Size (employees) ${ }^{(a)}$} \\
\hline & $\begin{array}{c}1-9 \\
10-49 \\
50-249 \\
250+\end{array}$ & $\begin{array}{c}2 \% \\
16 \% \\
31 \% \\
44 \%\end{array}$ & $\begin{array}{c}1 \% \\
37 \% \\
38 \% \\
40 \%\end{array}$ & $\begin{array}{c}45 \% \\
1 \% \\
0 \% \\
4 \%\end{array}$ & $\begin{array}{c}10 \% \\
10 \% \\
4 \% \\
4 \%\end{array}$ & $\begin{array}{c}0 \% \\
35 \% \\
24 \% \\
7 \%\end{array}$ & $\begin{array}{c}43 \% \\
1 \% \\
0 \% \\
0 \%\end{array}$ \\
\hline \multicolumn{8}{|c|}{ Sector $^{(\mathbf{a})}$} \\
\hline \multirow[t]{6}{*}{ Sector } & $\begin{array}{c}\text { Food \& } \\
\text { beverage* } \\
\text { Footwear }\end{array}$ & $14 \%$ & $25 \%$ & $17 \%$ & $8 \%$ & $19 \%$ & $19 \%$ \\
\hline & Construction* & $0 \%$ & $28 \%$ & $9 \%$ & $16 \%$ & $34 \%$ & $13 \%$ \\
\hline & Tourism* & $10 \%$ & $30 \%$ & $21 \%$ & $2 \%$ & $18 \%$ & $20 \%$ \\
\hline & & $22 \%$ & $23 \%$ & $9 \%$ & $15 \%$ & $23 \%$ & $8 \%$ \\
\hline & $\begin{array}{l}\text { Hospital } \\
\text { activities* }\end{array}$ & $65 \%$ & $6 \%$ & $12 \%$ & $18 \%$ & $0 \%$ & $0 \%$ \\
\hline & & $13 \%$ & $50 \%$ & $23 \%$ & $0 \%$ & $25 \%$ & $0 \%$ \\
\hline
\end{tabular}

Notes: (a)The numbers indicate percentages that horizontally sum to $100 \%$. 
Table 7: ICT and E-Business Profile within Clusters $(n=407)$

\begin{tabular}{|c|c|c|c|c|c|c|c|}
\hline & Variables(a) & Leader & Innova & Beginn & Unread & Late & Laggard \\
\hline & & Cluster & Cluster & Cluster & Cluster & Cluste & Cluster \\
\hline Technology for & Website & $96.9 \%$ & $67.3 \%$ & $49.1 \%$ & $97.2 \%$ & $61.7 \%$ & $28.6 \%$ \\
\hline $\begin{array}{l}\text { IManag. } \\
\text { Information }\end{array}$ & Intranet & $85.9 \%$ & $65.3 \%$ & $52.5 \%$ & $11.1 \%$ & - & - \\
\hline & Knowledge & & & & & & \\
\hline & Management & $32.8 \%$ & $8.6 \%$ & $23.7 \%$ & $2.7 \%$ & - & - \\
\hline & EDM & $46.8 \%$ & $15.3 \%$ & $28.8 \%$ & - & - & - \\
\hline & ERP & $81.2 \%$ & $36.5 \%$ & $27.1 \%$ & $25 \%$ & - & - \\
\hline & Accounting Software & $10.9 \%$ & $52.8 \%$ & $69.4 \%$ & $61.1 \%$ & $69.1 \%$ & $62.5 \%$ \\
\hline & $\mathrm{SCM}$ & $50 \%$ & $12.5 \%$ & $30.5 \%$ & $5.5 \%$ & - & - \\
\hline & CRM & $62.5 \%$ & $6.7 \%$ & $8.5 \%$ & $16.6 \%$ & $4.9 \%$ & - \\
\hline E-Orders & $0 \%-4 \%$ & $12.5 \%$ & $1.9 \%$ & - & $72.2 \%$ & $1.2 \%$ & - \\
\hline & $5 \%-10 \%$ & $76.5 \%$ & $96.1 \%$ & $96.6 \%$ & $11.1 \%$ & $97.5 \%$ & $100 \%$ \\
\hline & $11 \%-25 \%$ & $6.2 \%$ & - & $1.6 \%$ & $2.7 \%$ & $1.2 \%$ & - \\
\hline & $26 \%-50 \%$ & $3.1 \%$ & - & $1.6 \%$ & $11.1 \%$ & - & - \\
\hline & $51 \%-100 \%$ & $1.5 \%$ & $0.9 \%$ & - & $2.7 \%$ & - & - \\
\hline $\begin{array}{l}\text { E-Invoices } \\
\text { (send) }\end{array}$ & $0 \%-4 \%$ & $14.0 \%$ & $6.7 \%$ & $3.3 \%$ & $2.7 \%$ & $2.4 \%$ & - \\
\hline & $5 \%-9 \%$ & $7.8 \%$ & $92.3 \%$ & $94.9 \%$ & $33.3 \%$ & - & $100 \%$ \\
\hline & $10 \%-49 \%$ & $76.5 \%$ & - & - & $63.8 \%$ & - & - \\
\hline & $50 \%-100 \%$ & $1.5 \%$ & $0.9 \%$ & $1.6 \%$ & - & - & - \\
\hline $\begin{array}{l}\text { E-Invoices } \\
\text { (received) }\end{array}$ & $0 \%-4 \%$ & $15.6 \%$ & $2.8 \%$ & $1.6 \%$ & - & - & - \\
\hline & $5 \%-9 \%$ & $6.2 \%$ & - & $98.3 \%$ & $30.5 \%$ & - & $100 \%$ \\
\hline & $10 \%-49 \%$ & $76.5 \%$ & $96.1 \%$ & - & $61.1 \%$ & $97.5 \%$ & - \\
\hline & $50 \%-100 \%$ & $1.5 \%$ & $0.9 \%$ & - & - & - & - \\
\hline Internet & 56K (analogue) & $3.1 \%$ & $5.7 \%$ & $16.9 \%$ & $25 \%$ & $18.5 \%$ & $10.7 \%$ \\
\hline & ISDN & $20.3 \%$ & $25 \%$ & $33.8 \%$ & $30.5 \%$ & $34.5 \%$ & $51.7 \%$ \\
\hline & Broadband via DSL & $54.6 \%$ & $59.6 \%$ & $47.4 \%$ & $33.3 \%$ & $43.2 \%$ & $16.0 \%$ \\
\hline & Broadband via Cable & $15.6 \%$ & $6.7 \%$ & - & $5.55 \%$ & $25.9 \%$ & - \\
\hline & Direct fibre & $14.0 \%$ & $1.9 \%$ & - & - & - & - \\
\hline & $\begin{array}{l}\text { Wireless broadband } \\
\text { connection }\end{array}$ & $21.8 \%$ & $2.8 \%$ & - & - & - & - \\
\hline ICT budget & $0 \%$ & - & $4.8 \%$ & $3.3 \%$ & - & $1.2 \%$ & $3.5 \%$ \\
\hline & $1 \%-4 \%$ & $25 \%$ & $38.4 \%$ & $37.2 \%$ & $66.6 \%$ & $51.8 \%$ & $55.3 \%$ \\
\hline & $5 \%-9 \%$ & $53.1 \%$ & $49.0 \%$ & $44.0 \%$ & $25 \%$ & $44.4 \%$ & 37.5 \\
\hline & $10 \%-49 \%$ & $17.1 \%$ & $7.6 \%$ & $15.2 \%$ & $5.5 \%$ & $2.46 \%$ & $1.7 \%$ \\
\hline & $50 \%-100 \%$ & $4.6 \%$ & - & - & $2.7 \%$ & - & $1.7 \%$ \\
\hline
\end{tabular}

Notes:

(a) The numbers indicate percentages that vertically sum to $100 \%$. 
Table 8: ICT and E-Business Profile across Clusters $(n=407)$

\begin{tabular}{|c|c|c|c|c|c|c|c|}
\hline & \multirow[b]{2}{*}{ Variables ${ }^{(\mathbf{b})}$} & Leaders & $\begin{array}{c}\text { Innovato } \\
\text { rs } \\
\end{array}$ & $\begin{array}{c}\text { Beginner } \\
\mathbf{s} \\
\end{array}$ & $\begin{array}{l}\text { Unready } \\
\text { adopters }\end{array}$ & $\begin{array}{c}\text { Late } \\
\text { adopter }\end{array}$ & Laggards \\
\hline & & $\begin{array}{c}\text { Cluster } 1 \\
(n=64)\end{array}$ & $\begin{array}{c}\text { Cluster } 2 \\
(n=104)\end{array}$ & $\begin{array}{c}\text { Cluster } 3 \\
(n=59)\end{array}$ & $\begin{array}{c}\text { Cluster } 4 \\
(n=36)\end{array}$ & $\begin{array}{c}\text { Cluster } \\
5\end{array}$ & $\begin{array}{c}\text { Cluster } 6 \\
(n=56)\end{array}$ \\
\hline \multirow{8}{*}{$\begin{array}{l}\text { Technology } \\
\text { for Manag. } \\
\text { Information }\end{array}$} & \multirow{8}{*}{$\begin{array}{l}\text { Website } \\
\text { Intranet } \\
\text { Knowledge } \\
\text { EDM } \\
\text { ERP } \\
\text { Accounting } \\
\text { SCM } \\
\text { CRM }\end{array}$} & $23.7 \%$ & $26.7 \%$ & $11.1 \%$ & $13.3 \%$ & $19.1 \%$ & $6.1 \%$ \\
\hline & & $34.8 \%$ & $43 \%$ & $19.6 \%$ & $2.6 \%$ & - & - \\
\hline & & $46.7 \%$ & $20 \%$ & $31.1 \%$ & $2.2 \%$ & - & - \\
\hline & & $47.6 \%$ & $25.4 \%$ & $27 \%$ & - & - & - \\
\hline & & $45.2 \%$ & $33 \%$ & $13.9 \%$ & $7.9 \%$ & - & - \\
\hline & & $3.2 \%$ & $25.5 \%$ & $19 \%$ & $10.2 \%$ & $25.9 \%$ & $16.2 \%$ \\
\hline & & $49.2 \%$ & $20 \%$ & $27.7 \%$ & $3.1 \%$ & - & - \\
\hline & & $64.5 \%$ & $11.3 \%$ & $8.1 \%$ & $9.6 \%$ & $6.5 \%$ & - \\
\hline \multirow[t]{5}{*}{ E-Orders } & \multirow{5}{*}{$\begin{array}{c}0 \%-4 \% \\
5 \%-10 \% \\
11 \%-25 \% \\
26 \%-50 \% \\
51 \%-100 \%\end{array}$} & $21.6 \%$ & $5.4 \%$ & - & $70.3 \%$ & $2.7 \%$ & - \\
\hline & & $14.2 \%$ & $29 \%$ & $16.5 \%$ & $1.2 \%$ & $22.9 \%$ & $16.2 \%$ \\
\hline & & $57.1 \%$ & - & $14.3 \%$ & $14.3 \%$ & $14.3 \%$ & - \\
\hline & & $25 \%$ & $12.5 \%$ & $12.5 \%$ & $50 \%$ & - & - \\
\hline & & $33.3 \%$ & $33.3 \%$ & - & $33.4 \%$ & - & - \\
\hline \multirow{4}{*}{$\begin{array}{c}\text { E-Invoices } \\
\text { (send) }\end{array}$} & \multirow{4}{*}{$\begin{array}{c}0 \%-4 \% \\
5 \%-9 \% \\
10 \%-49 \% \\
50 \%-100 \%\end{array}$} & $42.9 \%$ & $33.3 \%$ & $9.5 \%$ & $4.8 \%$ & $9.5 \%$ & - \\
\hline & & $3.9 \%$ & - & $43.4 \%$ & $9.3 \%$ & - & $43.4 \%$ \\
\hline & & $19.8 \%$ & $38.9 \%$ & - & $9.3 \%$ & $32 \%$ & - \\
\hline & & & $33.3 \%$ & $33.4 \%$ & - & - & - \\
\hline \multirow{4}{*}{$\begin{array}{l}\text { E-Invoices } \\
\text { (received) }\end{array}$} & \multirow{4}{*}{$\begin{array}{c}0 \%-4 \% \\
5 \%-9 \% \\
10 \%-49 \% \\
50 \%-100 \%\end{array}$} & $52.6 \%$ & $15.8 \%$ & $5.3 \%$ & $15.8 \%$ & $10.5 \%$ & - \\
\hline & & $3.1 \%$ & - & $45 . \%$ & $8.5 \%$ & - & $43.4 \%$ \\
\hline & & $19.6 \%$ & $40 \%$ & - & $8.8 \%$ & $31.6 \%$ & - \\
\hline & & $50 \%$ & $50 \%$ & - & - & - & - \\
\hline \multirow{8}{*}{$\begin{array}{l}\text { Internet } \\
\text { Access(d) }^{(d)}\end{array}$} & \multirow{8}{*}{$\begin{array}{l}\text { 56K (analogue) } \\
\text { ISDN } \\
\text { Broadband via DSL } \\
\text { Broadband via } \\
\text { Direct fibre } \\
\text { connection } \\
\text { Wireless } \\
\text { broadband }\end{array}$} & $4 \%$ & $13 \%$ & $21 \%$ & $18 \%$ & $31 \%$ & $13 \%$ \\
\hline & & $10 \%$ & $21 \%$ & $16 \%$ & $9 \%$ & $21 \%$ & $23 \%$ \\
\hline & & $19 \%$ & $34 \%$ & $16 \%$ & $7 \%$ & $19 \%$ & $5 \%$ \\
\hline & & $48 \%$ & $32 \%$ & - & $10 \%$ & $10 \%$ & - \\
\hline & & & & - & - & - & - \\
\hline & & $82 \%$ & $18 \%$ & & & & \\
\hline & & & & - & - & - & - \\
\hline & & $82 \%$ & $18 \%$ & & & & \\
\hline \multirow[t]{5}{*}{ ICT budget $^{(a)}$} & \multirow{5}{*}{$\begin{array}{c}0 \% \\
1 \%-4 \% \\
5 \%-9 \% \\
10 \%-49 \% \\
50 \%-100 \%\end{array}$} & - & $50 \%$ & $20 \%$ & - & $10 \%$ & $20 \%$ \\
\hline & & $9.1 \%$ & $22.9 \%$ & $12.6 \%$ & $13.7 \%$ & $24.0 \%$ & $17.7 \%$ \\
\hline & & $19.2 \%$ & $28.8 \%$ & $14.7 \%$ & $5.1 \%$ & $20.3 \%$ & $11.9 \%$ \\
\hline & & $33.3 \%$ & $24.2 \%$ & $27.3 \%$ & $6.1 \%$ & $6.1 \%$ & $3 \%$ \\
\hline & & $60 \%$ & - & - & $20 \%$ & - & $20 \%$ \\
\hline
\end{tabular}

Notes:

(a) The numbers indicate percentages that vertically sum to $100 \%$.Moreover, Table 7 and Table 8 show e-business profile composition within and across the clusters. 
Cluster 1 ("Leaders") characterised by website construction (96.9\%), ERP (81.2\%), intranet (85.9\%), EDM (46.8\%), knowledge management (32.8\%), accounting software (10.9\%), SCM (50\%) and CRM (62.5\%). Additionally, the percentage of e-orders that companies of this cluster is between $5 \%$ and $9 \%$ (76.5\%). Regarding the e-invoices that companies of this cluster send is between $10 \%$ and $49 \%$ (76.5\%) and e-invoices received are between $10 \%$ and $49 \%$ $(76.5 \%)$. Finally, ICT infrastructure is characterised by the usage of broadband via DSL (54.6\%) and wireless broadband connection $(21.8 \%)$ while the amount of ICT budget that companies invest in ebusiness applications is estimated between $5 \%$ and $9 \%$ (53.1\% of the total businesses).

In conjunction with the ratios of the other five clusters, we name this cluster as "Leaders" having higher e-business and demographic ratios than others. It is apparent from the data included in Table 7 and Table 8, that Leaders are large companies that strategically use e-business applications to do their business. Leaders have the highest percentages of advanced e-business applications such as SCM and CRM. Moreover, Leaders rely upon ERP systems $(45.2 \%)$ while other companies rely more on accounting software, which is less sophisticated than ERP applications. To achieve all the above, Leaders afford to spend large sums of monies to e-business applications in relation to all other companies.

Cluster 2 ("Innovators") is characterised by the following figures: high website construction $(67.3 \%)$, Intranet (65.3\%), knowledge management (8.6\%), EDM (15.3\%), ERP (36.5\%), accounting software (52.8\%), SCM (12.5\%) and CRM (6.7\%). Table 7 shows that the e-orders that the companies of this cluster received online are in great majority between $5 \%$ and $10 \%$ (96.1\%). Moreover, the e-invoices that companies of this cluster send is between $10 \%$ and $49 \%$ (92.3\%) and e-invoices received are between $10 \%$ and $49 \%$ (96.1\%). Regarding the ICT infrastructure, Table 7 shows that companies of this cluster use broadband via DSL (59.6\%) and ISDN (25\%) while the amount of ICT budget that companies enhance their e- business applications is estimated between $5 \%$ and $9 \%$ (49\%).

Innovators Cluster is a group of companies that has similar demographic characteristics with Leaders, except that most Telecommunication companies belong to Leaders $(65 \%)$ than Innovators (6\%). Innovators are therefore companies in all sectors that appear to innovate more often than other companies in various ebusiness applications: The use of Intranet is high (65\%), the usage of applications such as EDM, ERP, and SCM is relatively higher than the other companies (except than Leaders) while most Innovators use ebusiness $(96.1 \%)$ for the $5 \%-10 \%$ of their orders. Therefore, while Leaders are more extensive users of e-business because of their leading position within each sector and particularly in the Telecoms, Innovators use e-business to innovate and sustain their competitiveness.

Cluster 3 ("Beginners") is characterised by a low percentage of website construction (49.1\%), Intranet (52.5\%), knowledge management (23.7\%), EDM (28.8\%), ERP (27.1\%), accounting software (69.4\%), SCM (30.5\%) and CRM (8.5\%). The percentage of e-orders that companies of this cluster received online is between $5 \%$ and $10 \%(96.6 \%)$ while the e-invoices usage between $5 \%$ and $9 \%$ is $(94.9 \%)$ and e-invoices received are between $5 \%$ and $9 \% \quad(98.3 \%)$. ICT infrastructure is characterised by the usage of broadband via DSL (47.4\%) and ISDN (33.8\%) while the amount of ICT budget is estimated between $5 \%$ and $9 \%$ (44\%).

Beginners Cluster is a unique group of companies, as about half of the small companies (45\%), having 1-10 employees, across all sectors belongs in this cluster. As small companies, they mainly use accounting software than ERP systems (in sharp comparison to Leaders), while having modest usage of other e-business applications. It is characteristic that only $49.1 \%$ of Beginners have developed their own website, meaning than more than half of them have no Internet presence. The modest percentages of applications such as SCM, CRM, e-ordering, and e-invoicing can be interpreted as a reaction to suppliers and/or customers demands. The total absence of Internet access via Cable or 
direct fibre connection (technologies that Leaders and Innovators use) can be interpreted as a lack of investing in ebusiness and reveals that these companies, Beginners, are in the beginning of their ebusiness experience.

Cluster 4 ("Unready Adopters") is characterised by website construction (97.2\%), accounting software (61.1\%), ERP (25\%), intranet (11.1\%), SCM (5.5\%) knowledge management (2.7\%), and CRM $(16.6 \%)$. Furthermore, the percentage of eorders is between $0 \%$ and $4 \%(72.2 \%)$. Regarding the e-invoices that companies of this cluster send is between $10 \%$ and $49 \%$ $(63.8 \%)$ and received e-invoices are between $10 \%$ and $49 \%$ (61.1\%). Finally, ICT infrastructure is characterised by the usage of broadband via DSL $(33.3 \%)$ and ISDN access $(30.5 \%)$ while the amount of ICT budget is estimated between $1 \%$ and $4 \%(66.6 \%)$.

Unready Adopters is the cluster with the less number of companies within it $(n=36)$, consisting of micro and small companies (83\%), half of them operating in the tourist sector. The 'tourist effect' in Unready Adopters can explain the high website presence of them, as tourist companies usually construct a website in order to advertise their services.

The same effect can also interpret high CRM percentages $(16.6 \%)$ which is higher than innovators (6.7\%). The difference in CRM applications is that tourist companies (and other companies within this group) use CRM as 'business as usual' while Innovators use CRM as a tool to innovate and differentiate themselves among other companies within the same sector. Small companies, such as Unready Adopters, cannot afford an Intranet $(11.1 \%)$ or SCM (5.5\%). The lack of EDM (0\%) systems and e-ordering $(72 \%)$ reveals that although there is a need to advance their systems, Unready Adopters lag behind, probably due to structural problems. One such problem could be the lack of available funds to invest in ICTs as $66.6 \%$ of Unready Adopters invest $1 \%-4 \%$ of their revenues to ICTS, and only $5.5 \%$ of them invest $10 \%$ $49 \%$ of their revenues, while 3 times more Beginners do so (15.2\%).

Cluster 5 ("Late Adopters") is characterised by accounting software (69.1\%) website construction (61.7\%), and CRM (4.9\%). Table 7 shows that e-orders is between $5 \%$ and $10 \%(97.5 \%)$ whereas e-invoices that companies send are between $10 \%$ and $49 \%$ $(97.5 \%)$ and e-invoices received are between $10 \%$ and $49 \%$ (97.5\%). ICT infrastructure is characterised by the usage of broadband via DSL (43.2\%) and ISDN access $(34.5 \%)$ and the amount of ICT budget is estimated between $5 \%$ and $9 \%$ (51.8\%).

Late Adopters is a cluster of small companies (10-49 personnel) across all sectors except telecommunications. Late Adopters totally lack any use of Intranet, Knowledge Management, EDM, ERP, and SCM. In comparison to smaller companies (clustered together in Beginners and Unready Adopters), they seem that they are not interested in e-business applications. Eorder is not arriving to Late Adopters either. Lost of them use DSL connection $(43.2 \%)$ which is a cheap and modest solution for Internet access. Their lack of interest in a broad spectrum of e-business applications reveal that Late Adopters are unmoved from the advances in ICTs, preferring to continue operating business the same way the operate for decades.

Finally, Cluster 6 ("Laggards") is characterised by accounting software $(62.5 \%)$ and website construction $(28.6 \%)$ E-orders is between $5 \%$ and $10 \%(100 \%)$ whereas e-invoices that companies send are between $5 \%$ and $9 \%(100 \%)$ and einvoices received are between 5\% and 9\% $(100 \%)$. The ICT infrastructure is characterised by the usage of ISDN $(51.7 \%)$ while the amount of ICT budget that companies use to enhance their e-business applications is estimated between $1 \%$ and $4 \%(55.3 \%)$.

Laggards resemble a group of companies similar to Late Adopters. A key difference is that Laggards are mostly micro companies (98\%) with 1-9 employees, across all sectors. It is characteristic that Laggards do not use the e-business applications that Late Adopters also avoid to use, yet, moreover, Laggards have a very low website presence.

It is apparent from the data in Table 7 and Table 8, that Laggards have totally missed all the evolution of e-business. For 
example, the most advanced of Laggards use DSL to access the Internet with many of them still use analogue lines, probably to check emails or for personal use.

\section{Validation of Cluster Solution}

The validation of clusters is necessary to be assessed in order to evaluate whether these six-clusters are homogeneous within clusters or heterogeneous between them. For this purpose, two types of multivariate analysis are used in order to examine the validation of clusters.

Primarily, multinomial logistic regression was used for four categorical variables, that were not included in two-step cluster analysis: ICT effectiveness on revenue growth, efficiency in business process, internal to work organisation, procurement cost of supply goods, quality of product and services and quality of customer service, ICT influence on competition in company's sector, internal processes differentiation ICT influence on organisational structure, task and job descriptions, education and training of employees and outsourcing decisions.

The -2 Log Likelihood ratio test measures each independent variable effect on our model of 6 clusters.

The analysis indicated 'good fit', which was statistically significant at $\mathrm{P}<0.001$ indicating the positive effect of contribution of the independent variables to our model (model's P=0.000, -2 Log Likelihood=119.91, $\quad$ chi-square $=275.2$, d.f $=165$ ). The Nagelkerke'e pseudo $R^{2}$ is 0.513 indicating that almost $52 \%$ of the variance is explained by variables.

Table 9: Likelihood Ratio Tests in Multinomial Logistic Regression

\begin{tabular}{|c|c|c|c|c|c|}
\hline & Categorical Independent Variables & $\begin{array}{c}-2 \text { Log } \\
\text { Likelihood }\end{array}$ & $\mathbf{X}^{2}$ & df & $\mathbf{P}$ \\
\hline Q.H4 & $\begin{array}{l}\text { 'What kind of influence did ICT have } \\
\text { on'... }\end{array}$ & & & & \\
\hline $\mathrm{a}$ & Productivity of your company & 934.064 & 15.350 & 15 & $0.427^{*}$ \\
\hline $\mathrm{b}$ & quality of customer service & 937.628 & 18.914 & 15 & $0.218^{*}$ \\
\hline $\mathrm{c}$ & the efficiency of business processes & 947.132 & 28.418 & 15 & $\begin{array}{c}0.019 * \\
*\end{array}$ \\
\hline $\mathrm{d}$ & quality of products and services & 935.386 & 16.671 & 15 & $0.339^{*}$ \\
\hline $\mathrm{e}$ & internal work organisation & 933.570 & 14.855 & 15 & $0.462^{*}$ \\
\hline $\mathrm{f}$ & revenue growth & 938.436 & 19.721 & 15 & $\begin{array}{c}0.183^{*} \\
*\end{array}$ \\
\hline $\mathrm{g}$ & procurement cost of supply goods & 947.282 & 28.568 & 15 & $\begin{array}{c}0.018^{*} \\
*\end{array}$ \\
\hline Q.H5 & competition in your sector & 941.002 & 22.287 & 10 & $\begin{array}{c}0.014^{*} \\
*\end{array}$ \\
\hline Q.I.3 & $\begin{array}{l}\text { 'During the past } 12 \text { months, has your } \\
\text { company introduced any new or } \\
\text { significantly improved internal } \\
\text { processes?' }\end{array}$ & 938.426 & 19.711 & 10 & $\begin{array}{c}0.032 * \\
*\end{array}$ \\
\hline Q.H7 & $\begin{array}{l}\text { 'Organisational aspects in company: } \\
\text { Did ICT have an important influence } \\
\text { on'... }\end{array}$ & 950.872 & 32.157 & 10 & 0.000 \\
\hline $\mathrm{a}$ & task and job descriptions & 941.810 & 23.095 & 10 & $0.010^{*}$ \\
\hline $\mathrm{b}$ & education and training of employees & 933.978 & 15.263 & 10 & $\begin{array}{c}0.123^{*} \\
*\end{array}$ \\
\hline c & outsourcing decisions & 929.645 & 10.930 & 10 & $\begin{array}{c}0.363^{*} \\
*\end{array}$ \\
\hline
\end{tabular}

* Significant at $\mathrm{P}<0.05$ level; ** Significant at $\mathrm{P}<0.001$ level 
Next, a stepwise discriminated function analysis is used for the same 8 categorical variables ( 4 sets) that were not measured in the two-step cluster analysis: ICT influences (7 items), competition, internal process, ICT organisational influences (4 items). The analysis indicated that $\mathrm{F}$ value has a significant effect on all the independent variables. Table 10 shows the four significant discriminated functions that explained the $100 \%$ of the total variance. Moreover, Table 11 shows a high level of Wilks' Lamda ratio fact which means that functions have suitably separated into clusters. Additionally, the $\mathrm{P}$ value indicates that $\mathrm{df}$ act better than chance at separating into groups.

Table 10: Discriminant Function Analysis

\begin{tabular}{|c|cccc}
\hline Function & Eigenvalue & Variance & Cumulative & $\begin{array}{c}\text { Canonical } \\
\text { Correlation }\end{array}$ \\
\hline 1 & $0.806(\mathrm{a})$ & $74.2 \%$ & $74.2 \%$ & 0.668 \\
2 & $0.230(\mathrm{a})$ & $21.2 \%$ & $95.3 \%$ & 0.432 \\
3 & $0.047(\mathrm{a})$ & $4.4 \%$ & $99.7 \%$ & 0.213 \\
4 & $0.004(\mathrm{a})$ & $0.3 \%$ & $100.0 \%$ & 0.060 \\
\hline
\end{tabular}

a) First 4 canonical discriminant functions were used in the analysis.

Table 11: Wilks' Lambda

\begin{tabular}{|c|cccc|}
\hline & $\begin{array}{c}\text { Wilks' } \\
\text { Test of Function(s) }\end{array}$ & $\mathbf{X}^{2}$ & df & P \\
\hline 1 through 4 & .428 & 319.688 & 20 & $0.011^{* *}$ \\
2 through 4 & .773 & 96.845 & 12 & $0.014^{* *}$ \\
3 through 4 & .951 & 18.828 & 6 & $0.034^{* *}$ \\
4 & .996 & 1.356 & 2 & $0.508^{*}$ \\
\hline
\end{tabular}

* Significant at $\mathrm{P}<0.05$ level; ** Significant at $\mathrm{P}<0.001$ level

Finally, the classification analysis indicated that $54.6 \%$ of the total cases in the 407 questionnaire sampling are classified correctly into 6 clusters. This rate is much higher than the random chance rate
$(16.7 \%)$ that was calculated on prior probabilities for groups. Hence, it can be estimated that the results of multivariate analysis are sufficiently well validated with the six clusters method.

Table 12: Classification Analysis for 6 Clusters

\begin{tabular}{|c|c|c|c|c|c|c|c|c|c|c|c|c|c|}
\hline \multirow[t]{3}{*}{ Clusters } & \multirow[t]{3}{*}{$\mathbf{N}$} & \multicolumn{12}{|c|}{ Predicted Group Membership } \\
\hline & & \multicolumn{2}{|c|}{ Cluster 1} & \multicolumn{2}{|c|}{ Cluster 2} & \multicolumn{2}{|c|}{ Cluster 3} & \multicolumn{2}{|c|}{ Cluster 4} & \multicolumn{2}{|c|}{ Cluster 5} & \multicolumn{2}{|c|}{ Cluster 6} \\
\hline & & $n$ & $\%$ & $n$ & $\%$ & $n$ & $\%$ & $n$ & $\%$ & $n$ & $\%$ & $n$ & $\% e$ \\
\hline 1 & 64 & 35 & $54.6 \%$ & 19 & $18.26 \%$ & 2 & $3.38 \%$ & 1 & $2.77 \%$ & 3 & $3.7 \%$ & 4 & $7.14 \%$ \\
\hline 2 & 104 & 19 & $29.68 \%$ & 56 & $53.84 \%$ & 6 & $10.16 \%$ & 4 & $11.11 \%$ & 12 & $14.81 \%$ & 7 & $12.5 \%$ \\
\hline 3 & 59 & 12 & $18.75 \%$ & 19 & $18.26 \%$ & 13 & $22.03 \%$ & 0 & $0 \%$ & 8 & $9.87 \%$ & 7 & $12.5 \%$ \\
\hline 4 & 36 & 8 & $12.5 \%$ & 5 & $4.8 \%$ & 1 & $1.69 \%$ & 12 & $33.3 \%$ & 7 & $8.64 \%$ & 3 & $5.35 \%$ \\
\hline 5 & 81 & 11 & $17.18 \%$ & 17 & $16.34 \%$ & 5 & $8.47 \%$ & 1 & $2.77 \%$ & 40 & $49.38 \%$ & 7 & $12.5 \%$ \\
\hline 6 & 56 & 2 & $3.12 \%$ & 19 & $18.26 \%$ & 6 & $10.16 \%$ & 2 & $5.55 \%$ & 11 & $13.58 \%$ & 16 & $28.57 \%$ \\
\hline
\end{tabular}

Note: Percentage of correctly classified cases $=54.7 \%$ Random chance rate $=16.7 \%$ 


\section{Limitations}

Due to the fact that our study is based on data of e-business market watch, the questionnaire was not pre-tested before the survey in order to increase the reliability and validity. Moreover, the ebusiness terminology that was used in the questionnaire survey was criticized as complicated (Selhofer et al. 2007). Respondents that found the questionnaire inappropriate or complicated were excluded, typically by abandoning the interviewing process.

The survey of E-Business Watch comprised only business with computer usage. This limits e-business profiling to companies with computer usage rather than the total business population. This limitation is not significant to the extent that most companies use computers and DSL is rapidly adopted in Greece (Tsiamis, 2008). Additionally, Greek enterprises may outsource some e-business applications. This may distort the cluster solution which is derived from expressed, actual ebusiness behavior

\section{Managerial Implications and Recommendations for Further Research}

The six clusters solution indicated that there are different business strategies and policies among SMEs towards e-business applications. The most technologically advanced SMEs were labeled as 'The Leaders', are characterized by high rates of Intranet (85.6\%), EDM (46.8\%), SCM (50\%), CRM (62.5\%) and high ICT investments (5\%-9\% with a percentage of total volume $53.1 \%$ ). Leaders signify the existence of a segment of companies characterized by technological performance. Cluster 1 includes large enterprises (50-249 employees) and this suggests further investigation: 'Is it possible that smaller firms follow this technological path of growth or is it impossible due to their limited ICT budget?'

The demographic segmentation allows us to understand the business behavior in Greece in relation to sophistication of ebusiness model strategies;for instance, cluster 6 'Laggards' includes companies in the construction sector not showing significant percentages of e-business applications. However, this low adoption is contrary to the annual report of the Greek National Statistical Service (2006) which was completed in 2006, the magnitude of construction investments was estimated almost at 580 million euros including new assets, alliances, technological investments, while the growth rate of the construction sector was estimated around 68\% (Tsiamis, 2008).

On the contrary, Pontikakis et al. (2006) found that $81 \%$ of the construction sector uses ICT applications, an approach which does not support the low rates of ebusiness adoption of Cluster 6. Thus, further investigation is suggested on the obstacles that prevent the construction sector from enhancing its technological applications and automation to planning process and further exploration of the factors that contribute to the profile estimation.

We suggest six types of e-business behavior which exist in Greek economy. There are probably more, which it could be revealed with a more sophisticated approach model, thus we suggest further investigation. However, we believe that the demographic profile of Greek business sector can be used in order for core segments to evaluate their position in the marketplace and to identify new trends and possible lack of technological infrastructure.

It seems that Greek businesses have adopted the notion of digital economy, making e-business investments for modernizing their operational process towards internet facilities. The majority of Greek businesses are SMEs lacking sufficient investment resources, a fact which negatively contributes to technological change. SMEs operational flexibility can be the tool for re-assessing their position in the European marketplace improving their position significantly, especially the ones which are related to retail such as food and footwear; and tourism as well.

Beyond the primary purpose of the study, the results have to be further compared in order to have a clear view of the current trends of Greek entrepreneurship and what 
are the potential needs for further technological development. However, due to the lack of Greek research based on cluster profiling towards e-business performance, this is difficult to achieve except for the studies that have already been discussed.

\section{Conclusion}

We aimed to investigate Greek entrepreneurship related to e-business adoption and to present the current trends of all Greek sectors. Evaluating the entire business sector, we surprisingly found that e-business infrastructure is much highly adopted than the European ones indicating that Greek companies have already integrated their performance with new and efficient technologies. Additionally, we found that the ICT budget for new capital investments is high, a fact which leads to the notion that Greek businesses aspire to continue to supply their business with new technological infrastructure, an obligatory strategy in such a competitive business environment.

Furthermore, trying to generate groups of similar attitudes towards e-business integration, using appropriate statistical analyses, we distinguished six clusters with significant characteristics of e-business applications with great homogeneity. We found that Cluster 1 'Leaders' have significant e-business adoption, a fact which can make them have great resistance to global competition. However, other sectors such as food and beverage, construction and hospital activities need to adopt more sophisticated e-business models in order to be more competitive and technologically equipped.

Greek businesses are usually motivated by other Greek businesses in order to adopt new technological applications waiting mainly to distinguish the potential chances and opportunities. Greek SMEs have to continuously modernize their operations and technologies in order to catch up with the very high standards of the more advanced technologically equipped European countries.

\section{Acknowledgements}

The authors would like to express their gratitude to e-Business-watch observatory (www.ebusiness-watch.org/) for allowing researchers to use the secondary data for analysis. The authors would like also to acknowledge the suggestions of two anonymous reviewers and the editor in revising the initially submitted manuscript. However, all errors remain of the authors.

\section{References}

Bakouros, Y., Mardas, D. \& Varsakelis, N. (2002). "Science Park, a High Tech Fantasy?: An Analysis of the Science Parks of Greece," Technovation, 22(2), 123-128.

Boutilier, S. \& McNaughton, R. B. (2006). "Collaboration, Proximity and Innovation," Innovation through Collaboration, (12), 175-202.

Cuervo, M. \& Menendez, A. (2006). “A Multivariate Framework for the Analysis of the Digital Divide: Evidence for the European Union-15," Information Management, (42), 756-766.

Eikebrokk, T. R. \& Olsen, D. H. (2007). “An Empirical Investigation of Competency factors effecting e-business success in European SMEs," Information Management, (44), 364-383.

Falk, M. (2005). "ICT-Linked Firm Reorganisation and Productivity Gains," Technovation, (25), 1229-1250.

Guerrieri, P. \& Meliciani, V. (2005). "Technology and International Competitiveness: The Interdependence between Manufacturing and Producer Services," Structural Change and Economic Dynamics, (16), 489-502.

Harris, J., De Long, D. \& Donnellon, A. (2001). "Do You Have What it Takes to Be An e-Manager?," Strategy \& Leadership, (29), 10-14.

Hayes, J. \& Finnegan, P. (2005) “Assessing the Potential of e-Business Models: Towards a Framework for Assisting 
Decision-Makers," European Journal of Operations Research, (160), 365-379.

Hedelin, L. \& Allwood, C. (2002). "IT and Strategic Decision Making," Industrial Management \& Data Systems, 102 (3), 125139.

Hidding, G. (2001). "Sustaining Strategic IT Advantage in the Information Age: How Strategy Paradigms Differ by Speed," The Journal of Strategic Information Systems, 10 (3), 201-222.

Horner-Long, P. \& Schoenberg, R. (2002) "Does e-Business Require Different Leadership Characteristics? An Empirical Investigation," European Journal, 20 (6), 611-619.

Johnson, P. F., Klassen, R. D., Leenders, M. R. \& Awaysheh, A. (2007). "Utilizing eBusiness Technologies in Supply Chains: The Impact of Firm Characteristics and Teams," Journal of Operations Management, (4), 356-366.

Lal, K. (2005). "Determinants of the Adoption of e-Business Technologies," Telematics and Informatics, (22), 181-199.

Lan, P. \& Du, H. H. (2002). "Challenges ahead E-innovation", Technovation, (22), 761-767.

Lasch, F., Le Roy, F. \& Yami, S. (2007) "Critical Growth Factors of ICT Start-ups," Management Decision, 45 (1), 62-75.

Ledz ,B. \& Nobis, C. (2007). 'The Changing Allocation of Activities in Space and Time by the Use of ICT-Fregmentation as the New Concept and Empirical Analysis," Transportation Research , (41),190-204.

Liagouras, G., Zambarloukou, S. \& Constantelou, A. (2004). 'The Long Road from Technology to Development: Impasses and Challenges of Technology Policy in Intermediate Economies,' Industrial Dynamics, Innovation and Development, 1-25.

Lu, J. and Zhang, G. (2003). "Cost Benefit Factor Analysis in E-Services,"
International Journal of Service Industry Management, 14 (5), 570-595.

Morgan, A., Colebourne, D. and Thomas, B. (2006) "The Development of ICT Advisors for SME Businesses: An Innovative Approach," Technovation, (26), 980-987.

Motiwalla, L., Khan, M. R. \& Xu, S. (2005). "An Intra- and Inter-Industry Analysis of eBusiness Effectiveness," Information and Management, (42), 651-667.

National Statistics Service of Greece, (2007). 'General Secretariat of National Statistical Service of Greece,' [online], [accessed on 01/03/2007], http://www.statistics.gr

Tsiamis, G. (2008). 'Use of ICTs in the Public \& Private Sector (In Greece), Greek Observatory for ICTs, (In Greek),' [online], [accessed on 3/2/2009] http://www.observatory.gr/page/default.a sp?la $=1 \& \mathrm{id}=2101 \& \mathrm{pk}=417 \&$ return $=183$

Okazaki, S. (2006). "What do we Know about Internet Adopters?: A Cluster Analysis," Information and Management, (43), 127-141.

Ozer, M. (2002). "The Role of Flexibility in Online Business," Business Horizons, 61-69.

Papathanassiou, E., Kardaras, D. \& Arkoumani, B. (2003). "Management Context and Impact of e-commerce in the Greek Food Industries," Logistics Journal Management, 16 (2), 134-144.

Parsons, E. (2002). "Charity, Retail: Past, Present and Future," International Journal of Retail \& Distribution Management, 30 (12), 586-594.

Pavic, S., Koh, S. C. L., Simpson, M. \& Padmore, J. (2007). "Could e-Business Create a Competitive Advantage in UK SMEs?," Benchmarking: An International Journal, 14 (3), 320-351.

Phan, D. D. (2003). "E-business Development for Competitive Advantages: A case Study," Information and Management, (40), 581-590. 
Pontikakis, D., Lin, Y. \& Demirbas, D. (2006). "History Matters in Greece: The Adoption of Internet-Enabled Computers by Small and Medium Sized Enterprises," Information Economics and Policy, (18), 332-358.

Porter, M. (2001). 'Strategy and Internet,' Harvard Business Review, March 2001, 6378.

Salmela, H. \& Spil, T. (2002). "Dynamic and Emergent Information Systems Strategy Formulation and Implementation," International Journal of Information Management, (22), 441-460.

Selhofer, H., Lilischkis, S., Karageorgos. G. \& O'Donnell, P. (2007). 'The European eBusiness Report 2006/07 edition A portrait of e-business in 10 sectors of the EU economy 5th Synthesis Report of the eBusiness W@tch,' [online], [Retrieved 12 February 2007], http://www.ebusinesswatch.org/key_reports/documents/EBR06. pdf.

Stone, M. (2003). "SME e-Business and Supplier-Customer Relations," Journal of Small Business and Enterprise Development, 10 (3), 345-353.

Winston, M. (1996). "Leadership of Renewal: Leadership for the Twenty-first Century," Management Development Review, 9 (7), 15-19.

Xanthidis, A. \& Nicholas, D. (2004). "Evaluating Internet Usage and eCommerce Growth in Greece," New Information Perspectives, 56 (6), 356-366.

Xirogiannis, G. \& Glykas, M. (2007). 'Intelligent Modelling of e-Business Maturity,' Experts Systems with Applications, (32), 687-702. 